\title{
Sustainability in the Formation and Development of Historical Cities: "Nicosia Historical City Texture"
}

\author{
By Zihni Turkan ${ }^{1}$
}

\begin{abstract}
The formation of the historical city texture of Nicosia, the capital of Cyprus, began during the Lusignan Period. St. Sophia Cathedral and St. Catherine Church, which have an important place in the formation of the texture, are two of the few works of art still surviving today. Being a period of destruction for the city, in general, The Venetian Period provided the city walls to Nicosia which still surround the historical texture. The Ottoman Period brought a change to the historical city texture and Islamic culture and Turkish Architectural construction style replaced the Christian cultures. A number of architectural works from this period, still existing within the walled city of Nicosia, provided a great contribution to the formation and development of the present day texture, as well as for its sustainability. The British Period is one which brought novelty to the city texture of Nicosia. With demolition of historical works and changes in the street and square dimensions, British Colonial Architecture displays the traces of the recent past. The administrative buildings constructed in place of the demolished Lusignan Palace, still serve at present. With the beginning of the Period of the Republic in 1960, Nicosia underwent a fast process of development as an important capital in the Middle East. The traditional visuality in the city texture left its place to contemporary constructions and formations. The inter-communal conflicts, which started in 1964 on the other hand, negatively affected the formation and development of the city texture, and there was a period of stagnation until the 70s. The new developments observed since the 70 s and the insufficiency of precautions to protect historical texture, caused a deterioration the city texture. With the position of an open-air museum, Nicosia with its history of over twenty-five centuries has a very rich historical city texture with the legacies of various cultures which reigned over Cyprus and is sustainable in the present, and is therefore an important cultural and touristic center
\end{abstract}

Keywords: Cyprus, Nicosia, Historical City Texture, Walled City, Sustainability.

\section{Introduction}

Nicosia placed in the Mesaoria Plain, in the center of Cyprus, founded well over two thousand five hundred years ago, has been thriving as the administrative center of the island for the last ten centuries. Taking its name from Levkontheon, which turned to Lefkosia - meaning poplar grove in Greek - the city possesses quite a long history, as excavations for various purposes revealed relics from the Bronze Age (Gürkan, 1989:3). Its origins dating back to times B.C., and always being chosen as a capital by different cultures which dominated Cyprus throughout history, resulted in the city obtaining a rich and continuously developing sustainable texture.

Kanlidere (The River Pedios), running through the city, added to the wealth of Nicosia with the fertile plains it created around itself. At the same time, being the capital of the island helped Nicosia develop and grow as a center of business and trade in a short time (Altan, 2006:309; Gürkan, 2006:11). 
The historical texture of the city that can be observed today was created and developed with the cultural heritage of Lusignans, Venetians, Ottomans, the British colonial period, the Cyprus Republic, and since 1964, with the divided cultural heritages of Turkish and Greek Cypriots.

The walled city center of Nicosia, incorporating the historical city texture, has been a resource for the history of the city by being the main material of travel notes for many travelers, who visited the place throughout history and described the evolution of the city texture in detail, based on observation. The walled city of Nicosia, with its architectural works as old as eight hundred years and belonging to different cultures, is a cultural mosaic and an open-air museum, providing richness for tourism. However, the physical and social factors, and the demographic change within the walled city have been affecting the historical city texture negatively and are damaging the texture.

\section{The Historical City Texture Of Nicosia}

The first formation of the historical city texture of Nicosia, which has always been the capital city of Cyprus during various different civilizations in its history and taking place in the city center today, surrounded by the city walls of the Venetian Period, began in the Lusignan Period. Having the quality of an open-air museum with so many cultural heritage works present today, the formation and development of the historical city texture of Nicosia can be observed chronologically as presented below:

\subsection{The Lusignan Period (1191-1489)}

This is the period when the first concrete cases about the creation of the historical texture of the city are observed. Taking over Cyprus from the Byzantines, the Lusignans chose Nicosia as the capital of the island and spent a part of the island's income on developing and improving the city. Thus, Nicosia grew and with its cathedral, palaces, churches, chapels, places of pilgrimage, monasteries, mansions, and orchards, its fame spread abroad (Gürkan, 2006:13; Balkan, 1998:50,58).

The Lusignans built the first walls around the city. Completed in 1383, the city walls were $7.64 \mathrm{~km}$ long and had five gates with suspension bridges (Keshishian, 1978:54), (Figure 1). Gothic style St. Sophia Cathedral (Selimiye Mosque), where Lusignan Kings were crowned as King of Cyprus and the second largest religious building of the city St. Catherine Church (Haydarpaşa Mosque) have a very important place in the creation of the texture of the city, and have survived to the present. Gothic doors, windows, and arches, remnants of the Lusignan period, seen in buildings constructed in later periods, also contribute to the historical texture. 


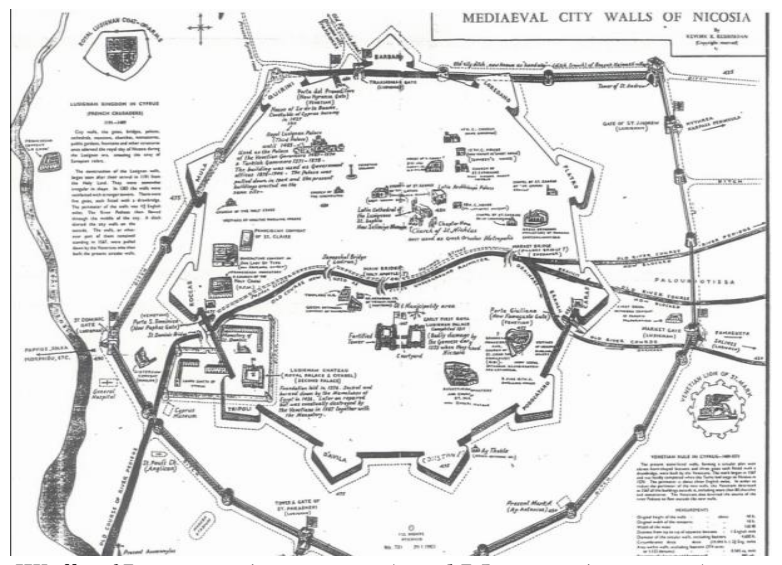

Figure. 1- Nicosia City Walls of Lusignan (1191-1489) and Venetian (1489-.....)

(K. K. Keshishian - Mediaval City Walls of Nicosia, 1959)

The Lusignan Palace, giving its name to the present day Sarayonönü (=courtyard) or Atatürk Square, has also left its mark on the texture of the city. Taking place in the north-west side of the square, the palace kept its administrative identity until the British colonial period (Gürkan, 2006:95,96; Keshishian, 1978), (Figure 2, 3).

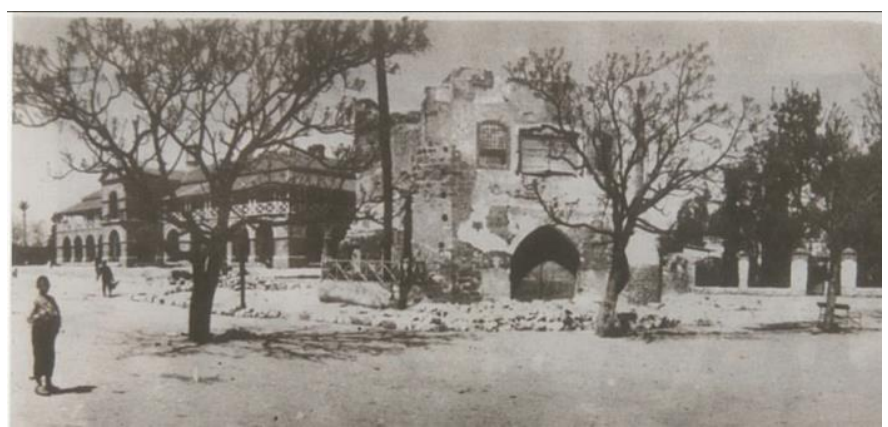

Figure 2- Lusignan Palace - 1905 (A. Saynl)

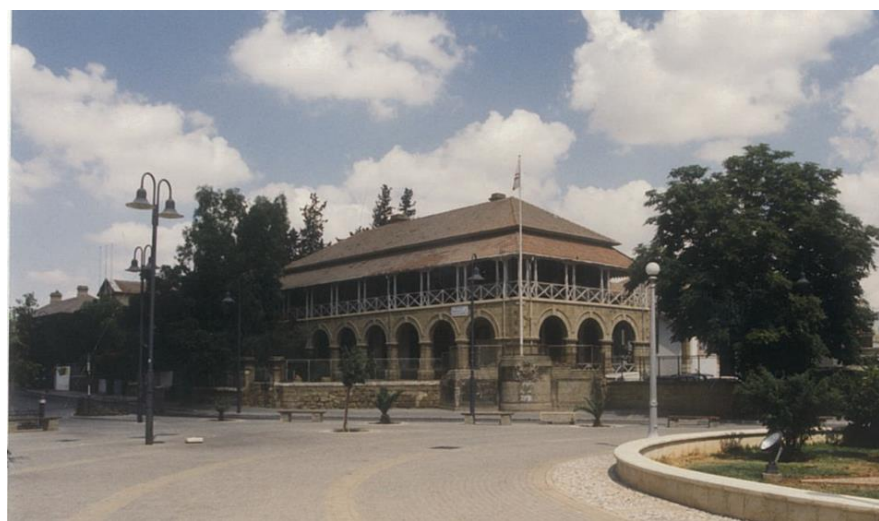

Figure 3- Public Administration Buildings (Court) - 2014 (Z. Turkan) 
An Italian public notary, named Nicolai Martoni, who came to Cyprus in November 1394, stated that there was a stream running through the center of Nicosia, and that people could only go across it by stepping on stones when it did not rain (Gürkan, 1989:8).

The oldest architectural works belonging to the creation of the historical city texture of present day Nicosia were built during the Lusignan Period and they form the initial pieces of the cultural mosaic of the city.

\subsection{The Venetian Period (1489-1570)}

Nicosia was the administrative center of the island during the reign of the Venetians as well. However, it lost the grandeur of the Lusignan Period, because most of the taxes collected in the island were sent to Venice, and no financial aid came to Cyprus from Venice, except for the military expenses.

As a precaution against possible assaults from abroad, the Venetians demolished city walls and many buildings of the Lusignans and made the city smaller (Cobham, 1908:41; Gürkan, 1989:21). This was a period of demolition for the urban texture of Nicosia. Using the stone blocks from demolished buildings, city walls were built stretching 4.82 $\mathrm{km}$ in circumference. The construction of the walls lasted three years and was completed in 1570. They contain eleven bastions and three gates (Kyrenia, Famagusta, and Paphos gates), and are still encompassing the historical texture of the city today (Altan, 2006:40; Salvator, 2012:9; Y1ld1z, 1994:197-206), (Figure 1).

The Venetian Column, which has its final place in the Sarayönü Square, was placed at the south of the Lusignan Palace as a symbol of Venetian sovereignty in Cyprus (Anonymous, 1978:3). Changing place in the square in later periods, the column preserves its place within the historical city texture today and is a symbol of the city.

Other important works contributing to the development of the historical urban texture of Nicosia are the Gothic style St. Nicholas Church (Bedesten) (Figure 4,5) next to St. Sophia Cathedral, the Venetian House (Stone Arts Museum) in the St. Sophia (Ayasofya) area, and the Venetian House near Turunçlu Mosque. St. Nicholas Church (Bedesten) has been restored and is now surviving as an important center hosting cultural and artistic activities.
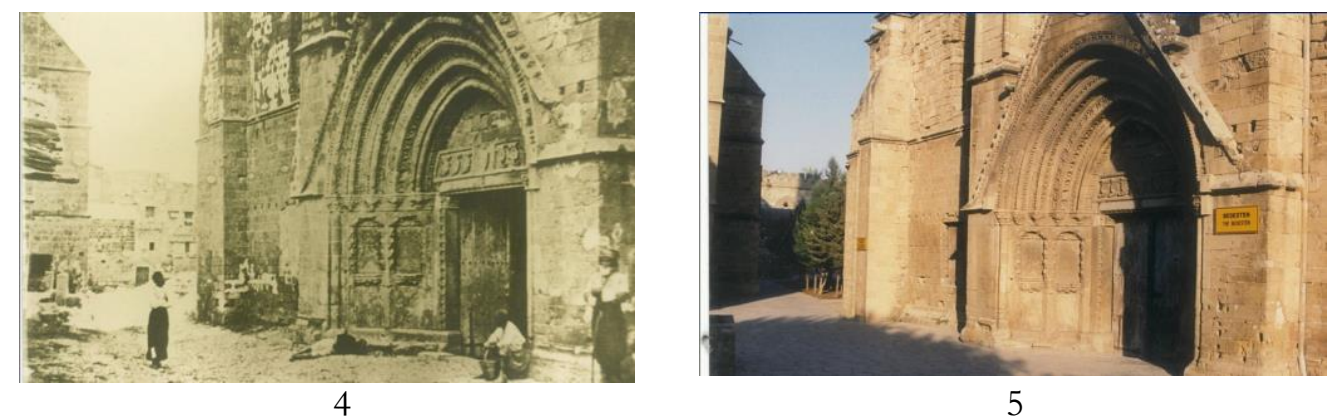

Figure 4- St. Nicholas Church (Bedestan) - 1878 (J. Thomson)

Figure 5- St. Nicholas Church (Bedestan) - 2014 (Z. Turkan) 
An English pilgrim, John Locke, who visited Cyprus in 1553, wrote about Nicosia as, "...the streets of the city are without plating and with its numerous gardens the city resembles a village. Yet, there are beautiful buildings in the city, and monasteries belonging to Franks and Greeks. The cathedral church is called Santa Sophia, which houses an old grave made of agate stone..." (Gürkan, 1989:18). Although the destruction of city texture by the Venetians caused great damage to the formation of texture which began during the Lusignan Period, the fact that city walls, still surrounding the historical city texture of Nicosia today, are of that period, have been a very important contribution the formation and sustainability of the historical city texture (Figure 6).

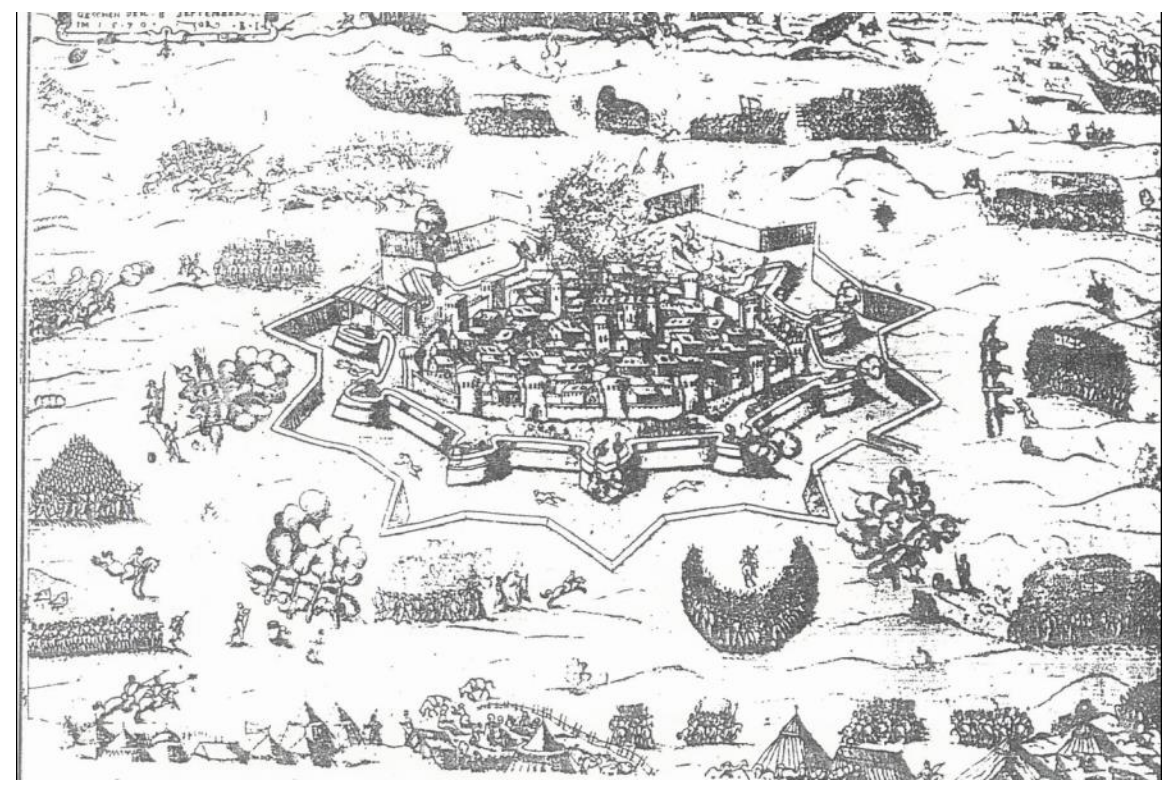

Figure 6- Ottoman Blockade of Nicosia (1570) (Map Department Office of T.R.N.C.)

\subsection{The Ottoman Period (1571-1878)}

With the island falling into the hands of the Ottomans in 1571, it became a province and Nicosia continued its identity as a center.

The Ottoman Period is an important one for the creation and development of the urban texture of Nicosia. During this period, the Venetian buildings continued to be used by altering their functions and in addition, new buildings were constructed in authentic Turkish architectural style. Mosques, inns, baths, mansions, fountains, belonging to the present day historical texture of the city were constructed during this period. Initially, some churches were turned into mosques in order to meet religious needs, by adding minarets, altars, pulpits, and women's sections. Some of these are the Selimiye Mosque (St. Sophia Cathedral (Figure 7, 8), Haydarpaşa Mosque (St. Catherine Church), Laleli Mosque (Medieval church), Ömerge Mosque (St. Augustin Church (Altan, 2006:44; Aslanapa, 1975:v1; Lukach, Jardine, 1913: 75,76; Salvator, 2012:30). 

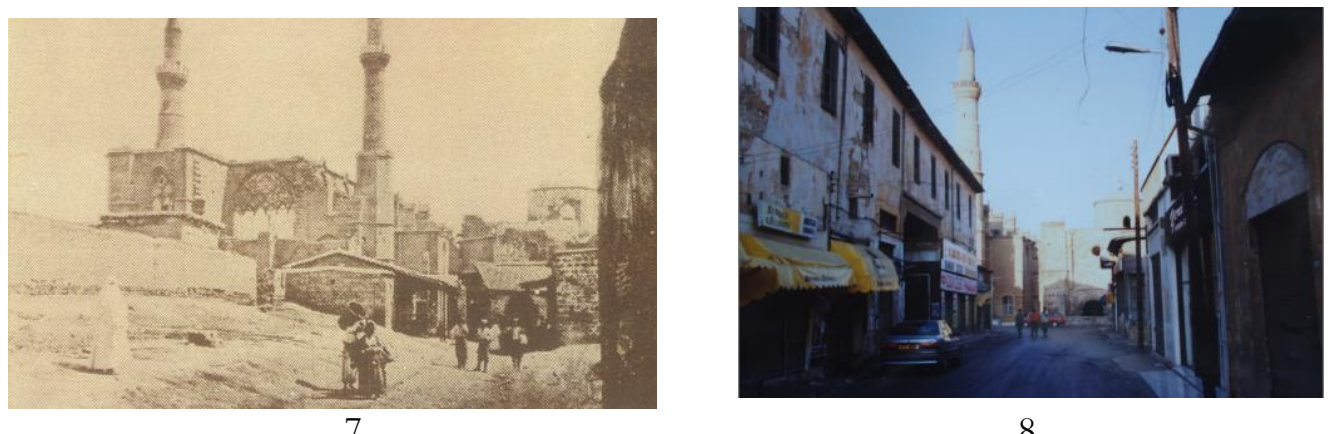

8

Figure 7- Selimiye Mosque (St. Sophia Cathedral) - 1878 (J.Thomson)

Figure 8-Selimiye Mosque (St. Sophia Cathedral) - 2014 (Z. Turkan)

Most of the works of the Ottoman Period are in Nicosia and had a great contribution to the development of the city texture. The main works of this period are Dükkanlar Önü Mosque (1816), Ordu Önü Mosque (1820), Bayraktar Mosque (1820), Turunçlu Mosque (1825), İplik Pazarı Mosque (1826), Arabahmet Mosque (1827), Mevlevi Tekke (XVII. Century), Aziziye Tekke, Büyük Han (Grand Inn) (1572), Kumarcılar Hanı (Gamblers Inn (XVII. Century), Ömerge Bath, Grand Bath, Korkut Bath, Sultan Mahmut II. Library (1829), Selimiye Fountain (XVIII. Century), Dükkanlar Önü Fountain, Laleli Fountain (1827),

Great Medrese Fountain (1827), Small Medrese Fountain (1827), Dry Fountain (1827), Fuzuli Street Fountain, Sarayönü Square fountain, Mevlevi Tekke Street Fountain, Kad1 (judge) Menteşoğlu Mansion, Derviş Paşa Mansion, Saçaklı Ev (Eaved House). The first building, constructed in the Turkish Architectural style, in Nicosia is the Büyük Han (Grand Inn) (1572) (Turkan, 2007:30-37; Anonymous, 1982:24), (Figure 9.10). A typical sample of intercity business inns of Anatolia, this building has been restored in accordance with the historical city texture and functioned to serve as an important culture-art center.

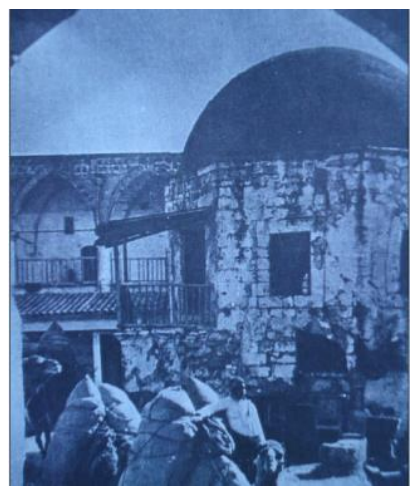

9

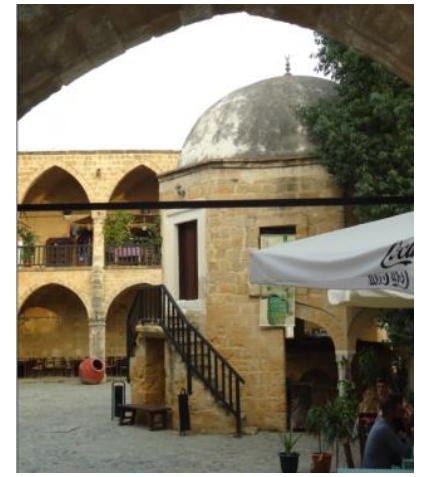

10

Figure 9- Great Inn - 1920 (M. Islamoglu)

Figure 10- Great Inn - 2014 (Z. Turkan) 
Straight and wide streets and large squares of the Lusignan and Venetian periods have been narrowed and turned into curved and dead-end streets in time, with the construction of new buildings. The textural change in housing, with the construction of Traditional Turkish House type buildings along these streets have been an important change from this period to the present. Arabahmet and Ayasofya neighborhoods, accommodating a very rich historical housing architecture, have developed an identity during this period (Figure 11, 12).

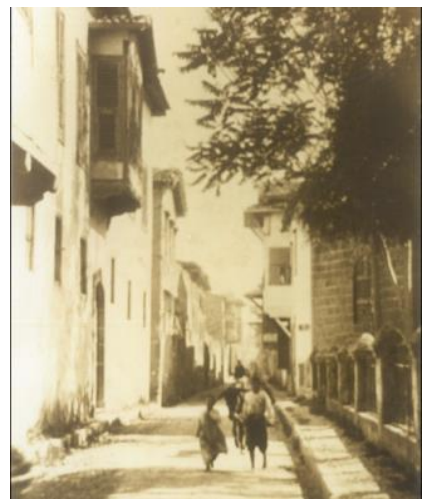

11

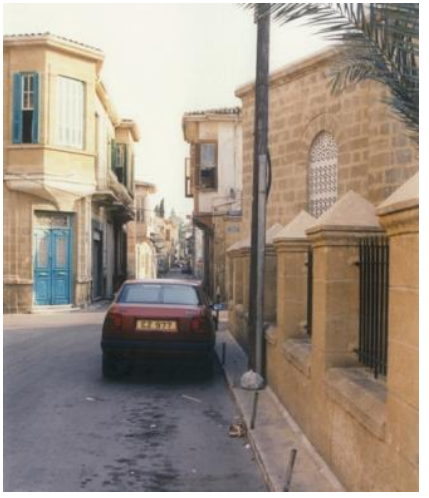

12

Figure 11-Victoria (Şht. Salâhi Şevket) Street - 1880 (J. P. Foscolo)

Figure 12- Sehit Salâbi Şevket Street - 2014 (Z. Turkan)

Nicosia became the business and crafts center of the island during the Ottoman Period. Twenty-three markets (Gazioğlu, 1994:209; Gürkan, 1989:122; Salvator, 2012:63), including the one known as Arasta today (Figure 13,14), brought a great liveliness to the business of the city.

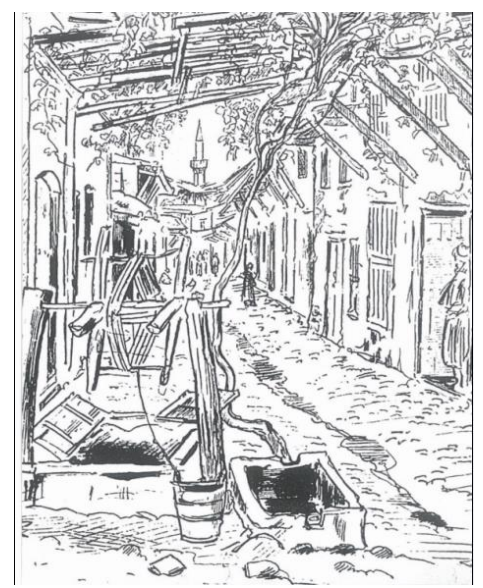

13

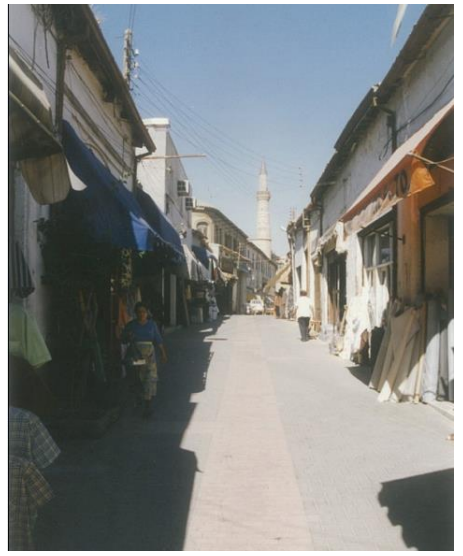

14

Figure 13-Arasta (Bazaar) - 1872 (L. Salvator)

Figure 14- Arasta (Bazaar) - 2014 (Z: Turkan) 
Visiting Nicosia in 1767, The Italian priest Giovanni Mariti, who was serving in Larnaca, emphasized in his writings that Nicosia was an important center of business and crafts (Gürkan, 1989:28,102).

With the changes and developments during the Ottoman Period, the city texture of Nicosia left its mark on the present day historical city texture. The Christian cultures visible in the city until this period, were replaced by the Islamic culture and the architectural style of this culture. Turkish architectural works became effective in the city.

\subsection{The British Period (1878-1960)}

With Cyprus coming under British sovereignty in 1878, Nicosia preserved its place as the center and capital of the island. During this period, constructions in the city continued showing the effects of Ottoman Architecture, especially in housing. Later, parallel to economic development, buildings multi-story buildings were constructed from cut stone (ashlar), with ornamented façades.

English writer W.Hebworth Dixon, who visited Cyprus in the first months of the British Period, wrote in his book British Cyprus, which he published a year later, that Nicosia resembled a labyrinth with its narrow streets and passages, that most of the houses were built with mud brick, and that there was not a single street that was straight (Dixon, 1879:part15).

Not being very meticulous about preserving old works, the British carried out demolitions for redesigning the city, and the Lusignan Palace, which served as the administrative center since the Lusignan Period, was demolished in 1901 (Bağışkan, 2005:343; Turkan, 2008:23). The public works building, known as the Court Buildings, was erected in the place where the palace once stood, in British Colonial Architectural style (Figure 2, 3). As motor vehicles arrived in the island during this period, demolitions were carried out to create wider streets and main roads in place of the insufficient narrow streets of Nicosia. City walls on both sides of the Kyrenia Gate were also demolished in order to provide access for motor vehicles in and out of the walled city (Gunnis, 1973:46), (Figure 15, 16).

English journalist George Blount Pusey, in his memoirs of 1934, says, “... Nicosia is a Turkish city in form. It is a labyrinth of streets, stranded within the orderly Venetian walls. The streets are so narrow that people can shake hands from the bay windows of the upper floors, facing each other..." (Gürkan, 1989:66).

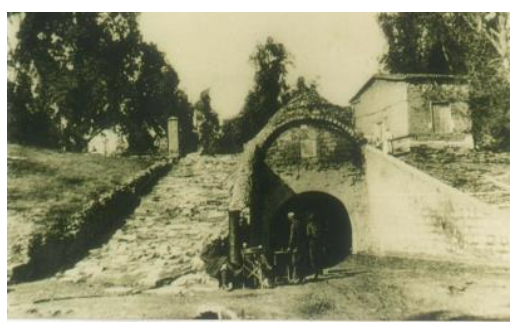

15

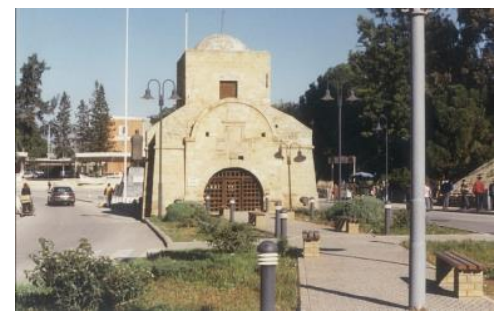

16

Figure 15- Kyrenia Gate - XIX. Century (B. Pulhan)

Figure 16- Kyrenia Gate - 2014 (Z. Turkan) 
With the city texture of Nicosia developing during the British Period, they city began to extend outside the city walls, and new neighborhoods arose with buildings authentic to this period. Menteşzade İsmail Hakkı Efendi, in whose writings we understand he described the external parts of the city, wrote in his impressions in 1930 that he could not have enough of observing the chateaus ornamented with gardens, the pleasant woods, and wide streets (Menteşzade, 1930:No.322).

Besides the harm done, as is reflected on the historical city texture during this period, the advantage of the economic prosperity yielded a different gain for the texture of Nicosia in the shape of British Colonial Style constructions.

\subsection{The Period of the Republic of Cyprus (1960-1964)}

The capital city of the Republic of Cyprus, founded in 1960 based on the joint administration by Turkish and Greek Cypriots, is still Nicosia. During this period, which lasted quite short, the island became an important transit point in the Middle East, and Nicosia being the capital of a new republic, increased social and business activities in the city, placing it in a process of rapid development. Multi-story concrete buildings, a product of new type of construction, gave a new look to the traditional visual texture of the city.

Two of the first constructions of this period, Saray Hotel and the Cyprus Turkish Cooperative Central Bank buildings (Turkan, 2008:27) were constructed around Sarayönü Square, the center of historical city texture of the walled city, and added a new dimension to the city texture (Figure 17,18).

The contemporary formation that started in the city during this period resulted in a distinctive process of change in the historical city texture of Nicosia.

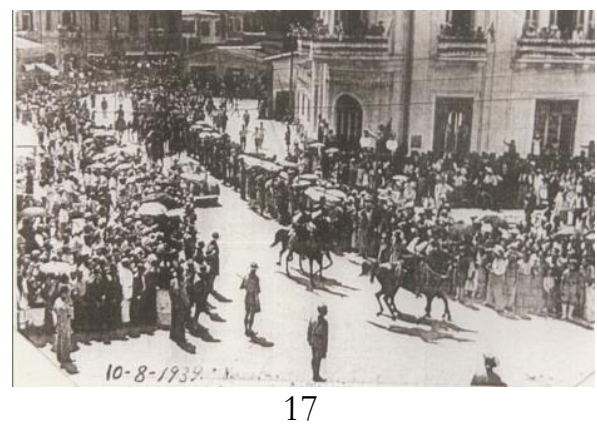

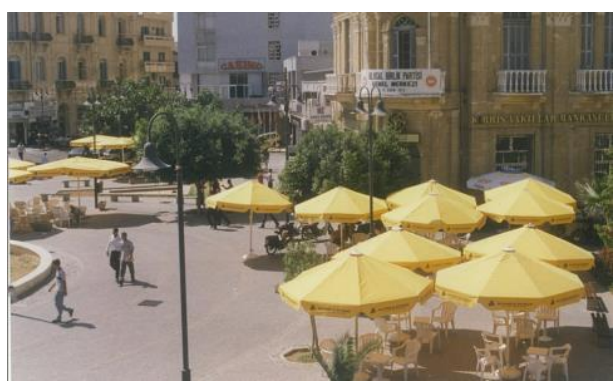

18

Figure 17- Sarayönü Square - 1939 (A. Saynl)

Figure 18-Sarayönü Square - 2014 (Z. Turkan)

\subsection{After The Period of the Republic of Cyprus (1964-74):}

The political and armed conflict that began between the Turkish and Greek communities in the last days of 1963, in Cyprus, negatively affected Nicosia, and the city was divided into two parts from the beginning of 1964. This division divided the walled city, which houses the historical city texture, into two, almost equal parts. New formation, arising parallel to the economic superiority of the Greek side, and the rapid development in south Nicosia, brought negative reflections to the historical city texture. The city texture process of North Nicosia on the other hand, entered a stable period, and 
constructions came to an end. However, the migrations within the Turkish population (people taking refuge in safer places) increased the population of the Turkish part of Nicosia, bringing with it the problem of lodging. Not having sufficient housing to meet the need in the city, made it compulsory to use many historical buildings in the walled city for residential purposes. Such usage caused damage to historical building, giving harm to the historical city texture.

\subsection{From 1974 to Today:}

On July 15, 1974, Greek Cypriots staged a coup with the aim of uniting Cyprus with Greece. In return, as one of the guarantor states of the Republic of Cyprus, Turkey started the Cyprus Turkish Peace Operation, which registered the division of Nicosia, and the area of the Turkish part increased (Figure 19).

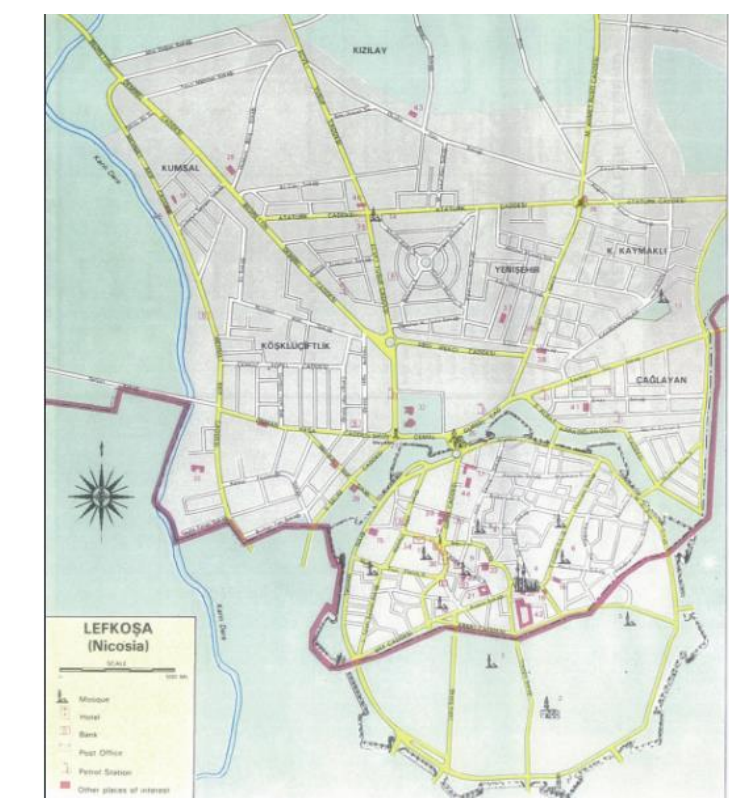

Figure 19- Town Plan of North Nicosia - 1990 (Ministry of Tourism of T.R.N.C.)

While South Nicosia continued to be the capital of the Republic of Cyprus, North Nicosia became the capital of the Turkish Federated State of Cyprus, which was declared on February 13, 1975. The new constructions that began in North Nicosia within the process of development, caused deteriorations in the historical city texture, because they were not in harmony with the historical texture and were uncontrolled (Figure 20, 21). Directorate of the Department of Antiquities and Museums, founded in 1975, started work on the preservation of ancient buildings in 1977 (Yardımc1, 1979:549-551), and took precautions to preserve the historical city texture in cooperation with the Public Works Department of the Turkish Municipality of Nicosia. The Higher Council of Immovable Ancient Works and Monuments also undertook an effective role in preservation and new constructions. 

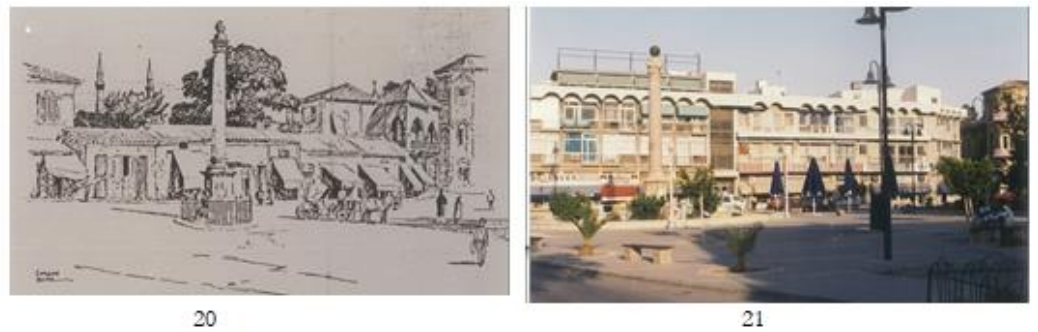

Figure 20- Sarayönü Square-End of 1800 (G. Home)

Figure 21-Sarayönü (Atatürk) Square- 2014 (Z. Turkan)

In 1981, Turkish and Greek parts of the walled city were taken as a whole within the scope of the Nicosia Master Plan, financed and coordinated by the United Nations, and a new pedestrian and traffic flow plan was drawn and implemented.

New constructions, observed much faster and more during these years, as a result of the economic superiority of the Greek side, brought about great contradictions with the historical texture. As the northern part of the walled city preserved the character of a historical city in spite of everything, the southern part took the appearance of a new city. Northern Nicosia, which became the capital of the Turkish Republic of Northern Cyprus, founded on November 15, 1983 as a result of an administrative change in north Cyprus, entered a period of more rapid development compared to previous periods. Due to the increase in importance of the city being a business center besides its administrative identity, majority of inhabitancy in the historical city texture, moved outside the walls fast, and historical buildings changed hand either by renting or by selling. The use of buildings within the walled city for profit resulted in physical destruction, harming the historical texture. The rapid change of the demographic structure of the walled city, and improper use of historical buildings increased unconscious alterations. Besides all these problems, the political power not executing its duty of legal applications and inspections because of its populist approach is resulting in the deterioration of the rich historical city texture of northern Nicosia and causing unrecoverable losses.

Although having a much weaker historical texture concerning the number and quality of historical works compared to northern Nicosia, more emphasis has been given to preservation in the southern part of the walled city in recent years. However, neither part has done much to preserve the historical city texture compared to similar places in the world (Figure 22, 23).

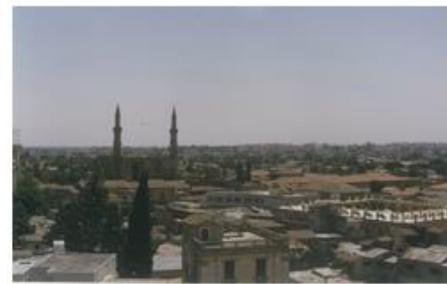

22

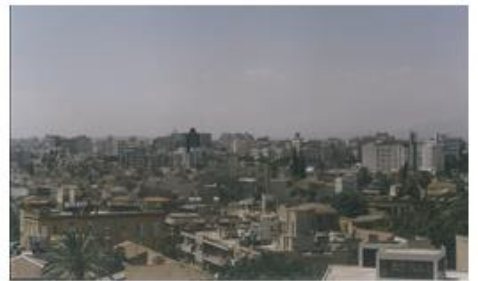

23

Figure 22- North Nicosia - 2014 (Z. Turkan)

Figure 23- South Nicosia - 2014 (Z. Turkan) 


\section{Conclusion}

The formation of the present day historical city texture of Nicosia encompasses a period of over eight hundred years, starting with the Lusignan Period. Formed and developed with the contributions of different cultures throughout this period of time, the city texture has transmitted a very rich heritage to the present in the form of a cultural mosaic, formed by many architectural works.

However, the walled city containing the historical city texture, which accommodated the whole city in the past, has become just one neighborhood of the city at present, the old city center, due to the physical, economical, and social changes taking place in Nicosia.

The city texture of Nicosia that is growing and developing outside the walls is directing residences, public administration, business, and social life buildings out of the walls as well. The new constructions developing with this formation in the city, lowered life within the walled city to a secondary level, thus causing it to lose its economic value. Lately, the walled city of Nicosia has been handed over to a generally lower income demographic character, which is stranger to the city. Moreover, the political and inspectional incompetence of those institutions in charge of protecting the historical city texture and planning new urban formations have been affecting the development of the texture in an erroneous and negative way, and causing great damage to the present elements of the historical texture.

Being an important capital in the Middle East and the Eastern Mediterranean, Nicosia, with a population of over a hundred thousand and eight active private universities, with its present day activities in tourism, business, culture, and education, is gaining more importance for its future. Providing a life suitable to the historical city texture and enabling sustainability by creating a city texture developing in the right direction can only be realized with the private sector, civil society organizations and individual enterprises besides government resources. The physical planning and applications of the city can be realized with socio-cultural planning as well.

The walled city of Nicosia, in a position as a museum-city, can have an important place in global tourism as the tourism center of the island, offering lodging, and business activities together, with the loading of authentic functions to it. Moreover, having a great potential with the recently rising education sector in the island, it should set an example as a center bringing together the concepts of historical city texture, tourism, culture, and art in a common ground, where its higher education institutions can bring life to the fields of culture and arts; nurturing them in its bosom.

\section{References}

Altan, Z. (2006). Giz̨emli Kıbrıs. Lefkoşa: Ateş Matbaacilık Ltd.

Anonymous. (1978). Lefkoșa Şehri Müze ve Eski Eserleri. Lefkoşa: Kıbrıs Türk Müzelerini ve Eski Eserleri Sevenler Derneği Yayını.

Anonymous. (1982). Kıbrıs'ta Türk Eserleri. Lefkoşa: Kıbrıs Türk Federe Devleti Eğitim, Geçlik, Kültür ve Spor Bakanlığı Eski Eserler ve Müzeler Dairesi Müdürlüğü Yayını.

Aslanapa, O. (1975). Kıbrs'da Türk Eserleri. İstanbul.

Bağışkan, T. (2005). Kıbrıs'ta Osmanl - Türk Eserleri. Lefkoşa.

Balkan, A., E. (1998). Taribsel Sürȩ̧ İerisinde Kuzey Kıbrıs Türk Cumburiyetinde Toplum ve Mimarllk. Mağusa. 
Cobham, B. (1908). Excerpta Cypria, Cambridge.

Dixon, H., W. (1879). British Cyprus, London.

Gazioğlu, C, A. (1994). Kıbrıs'ta Türkler (1570-1878). Lefkoşa.

Gunnis, R. (1973). Historic Cyprus. Nicosia:K. Rüstem \& Bro.

Gürkan, M., H. (1989). Dünkü ve Bugünkü Lefkoșa. Lefkoşa: Lefkoşa Belediye Yayınları, No:5

Gürkan, M.,H. (2006). Dünkü ve Bugünkü Lefkoşa. Lefkoşa: Galeri Kültür Yayınları.

Keshishian, K., K. (1978). Nicosia Capital of Cyprus Then and Now. Nicosia.

Lukach, H.C. and Jardine, D.J. (1913). The Handbook of Cyprus. London: Edward Stanford Ltd.

Menteşzade, H., İ. "Lefkoşa", Birlike Gazetesi. No:322 (30 Haziran 1930), Lefkoşa.

Salvator, L. (2012). kıırıs'm başkenti Levkosia. Lefkoşa: Galeri Kültür Yayınları.

Turkan, Z. (2007). “Osmanlı Şehiriçi Ticaret Hanlarına Kıbrıs'tan İki Örnek: Büyük Han ve Kumarcılar Hanı", I. International Architecture \& Stone Symposium. Antalya Expo Center (November 2007). Antalya. pp. 30-37.

Turkan, Z. (2008). The Formation And Development Of SAR AYONU SQUARE Within The Historical City Texture Of Nicosia. Lefkoşa: Işık Kitabevi Yayınları, No:52.

Yardımcı, N. (1979). "K. T.F. D.'nin Eski Eserleri Korumak için Almıș Olduğu Tedbirler”, VIII. Türk Tarih Kongresi Bildirileri. Ankara. pp. 549-551.

Yıldız, N. (1994). “Tarihi Çevre”, K.K.T.C.'de Cevre Sorunlar Semposyumu. Lefkoşa. pp. 197-20 206. 